\title{
What does the Paris Agreement actually do?
}

\author{
David Campbell \\ Lancaster University Law School, UK
}

\section{Correspondence address}

Lancaster University Law School, Lancaster University, Lancaster, LA1 4YN, UK

\begin{abstract}
Though very widely believed to be inadequate in the target it sets, the Paris Agreement is commonly thought actually to set a binding target of reducing global $\mathrm{CO}_{2} \mathrm{e}$ emissions so as to limit global warming to $2^{\circ} \mathrm{C}$. Proper legal interpretation of the Agreement shows it to set no such target. It rather gives the newly industrialising countries such as China and India a permission to emit as much as they see fit. These countries have been principally responsible for the huge growth in emissions since 1990 and they will be responsible for their continued huge growth until 2030. The Paris Agreement therefore makes the policy of mitigation of global warming impossible. This, however, has been the case over the now more than a quarter century of international climate change policy.
\end{abstract}

\section{Keywords}

global emissions reductions; international climate change law; Paris Agreement

\section{Acknowledgements}

I am grateful to the Editor and her reviewers for their comments. 


\section{What does the Paris Agreement actually do?}

Fanaticism consists in redoubling your efforts when you have forgotten your aim.

Santayana, The Life of Reason, 1905

\section{Introduction}

At the kind invitation of the Editor, I have submitted this article, which is a revised version of Evidence submitted to the Inquiry into setting the UK's Fifth Carbon Budget by the House of Commons Select Committee on Energy and Climate Change [1]. ${ }^{1}$ This Evidence was submitted in March 2016 and this revised version now attempts to state the law as of September 2016. As one would expect of an article with such an origin, it has little theoretical ambition. Written by an academic lawyer, it merely attempts to correct the common misinterpretation of the Paris Agreement (PA) [2] that it reaches a binding agreement to limit global anthropogenic greenhouse gas $\left(\mathrm{CO}_{2} \mathrm{e}\right)$ emissions. Rather, properly interpreted, the PA actually strengthens the permission to emit as much as they see fit to the developing countries which has been the core feature of international climate change law since the opening for signature of the United Nations (UN) Framework Convention on Climate Change (FCCC) [3] in 1992. As the developing countries include the newly industrialising countries (NICs) such as China and India, and as the NICs are principally responsible for the huge growth in global emissions since 1990, and will be responsible for their continued huge growth through to 2030, this means that international climate change action under the PA cannot possibly meet its goals, and the policy of mitigation of global warming cannot possibly succeed. However, the impossibility of the mitigation policy has been the central feature of the entire history of international climate change action [4], which one now might date back more than a quarter 
century to the establishment of the Intergovernmental Panel on Climate Change (IPCC) in $1987[5$, para 5].

Though, as I have said, this article is of limited theoretical ambition, I will conclude it with some brief reflections on the significance of the international climate change policy of mitigation for regulatory theory and practice.

\section{A common misinterpretation}

A convenient statement of the common misinterpretation of the PA which I seek to correct has been provided by the extremely widely read 'anti-capitalist' commentator and activist Naomi Klein in the Edward Said Lecture she delivered on 5 May 2016 [6]. Klein claimed that:

The Paris Agreement commits to keeping warming below $2{ }^{\circ} \mathrm{C}$. It's a target that is beyond reckless. When it was unveiled in Copenhagen in 2009, the African delegates called it "a death sentence". The slogan of several low-lying island nations is " 1.5 to stay alive". At the last minute, a clause was added to the Paris Agreement that says countries will pursue "efforts to limit the temperature increase to $1.5^{\circ} \mathrm{C}$ '. Not only is this non-binding but it is a lie: we are making no such efforts.

Klein here emphasised the common criticism of the PA for not doing nearly enough when it set the $2{ }^{\circ} \mathrm{C}$ target and the level of global emissions reductions it implies, but she at least acknowledged the setting of a target. This is incorrect.

The first substantive provision of the PA, Art 2.1, provides:

This Agreement, in enhancing the implementation of the [FCCC], including its objective, aims to strengthen the global response to the threat of climate change, in the context of sustainable development and efforts to eradicate poverty, including by:

(a) Holding the increase in the global average temperature to well below $2^{\circ} \mathrm{C}$ above pre-industrial levels and pursuing efforts to limit the temperature increase to $1.5^{\circ} \mathrm{C}$ above pre-industrial levels, recognizing that this would significantly reduce the risks and impacts of climate change.

In order to evaluate Klein's interpretation of the PA it is necessary to take up Art 2.1's

references to the 'objective' of the FCCC and to a ' $2{ }^{\circ} \mathrm{C}$ ' limit in some detail. 
In Art 2.1, the FCCC states that its 'ultimate objective ... is to achieve ... stabilization of greenhouse gas concentrations in the atmosphere at a level that would prevent dangerous anthropogenic interference with the climate system'. This objective is obviously very vague, indeed it is tautological. Despite a profound concern to do so, international climate change negotiations between the FCCC and the PA were unable to set a concrete, legally binding target for warming, and therefore global emissions concentration, and for the global reductions necessary to achieve that target. Though I will not argue it here but merely refer the reader to earlier work $[4 ; 8 ; 9 ; 10]$, the concrete reductions required of developing countries by Art 3.1 of the 1997 Kyoto Protocol (KP) [7] were unrelated to any global target and can be defended only as a way of getting the ball of international climate change action rolling, and international climate negotiations between the KP and the PA did not establish any further binding commitments. What were often portrayed as such commitments were merely the reported decisions, resolutions and the like of the Parties' extensive negotiations and had no legal force whatsoever. The FCCC, the KP and the PA, if and when it enters into force, are the only Treaties international climate change negotiations have ever yielded.

By the ' $2{ }^{\circ} \mathrm{C} \ldots$ target', Klein of course means the now very widely discussed goal of reducing emissions so that global warming is limited to $2^{\circ} \mathrm{C}$ above pre-industrial temperatures. But it is important to be clear what she conveys by 'unveiled' when she says that this target 'was unveiled in Copenhagen in 2009'. She is of course referring to the Copenhagen Accord [11] (CA) which was the result of the fifteenth Conference of the Parties (COP) to the FCCC held in Copenhagen in 2009. If, accepting that prevention of global warming is not possible, one is going to pursue a policy of mitigating that warming, it would seem necessary to agree a target warming and a target concentration of $\mathrm{CO}_{2} \mathrm{e}$, and then to agree emissions reductions by the national authority Parties which have the capacity to make 
those reductions in order to stabilise the global, target concentration. But prior to the PA those negotiations had never in any proper sense agreed the $2^{\circ} \mathrm{C}$ or any other target.

Despite the mistaken belief, under which Klein herself does not labour [12, pp 12-13], that the $\mathrm{CA}$ itself represents the agreement of the $2^{\circ} \mathrm{C}$ target, the $\mathrm{CA}$ actually represents the complete failure to agree any such target. COP15 was indeed unable to agree anything at all through proper UN negotiating channels, and was saved from utter embarrassment only by the action of a self-selecting group of five countries - Brazil, India, the PRC, South Africa and the US - which drafted the CA, which, far from being a treaty commitment or the like, is an informal document of no legal status that appears in the Report of the COP15 proceedings as something of which the Parties merely 'took note'. The most important thing about the CA is that it marked the absence, not the presence, of agreement. Though I have done so in the earlier work to which I have referred [8, pp 434-36; 10, pp 402-404], I shall not demonstrate that what the CA says of the $2{ }^{\circ} \mathrm{C}$ target is itself non-committal. The point is that the neither the $\mathrm{CA}$ nor anything else between the $\mathrm{KP}$ and the PA constitutes the agreement of the $2{ }^{\circ} \mathrm{C}$, or any, target.

What we might call the official 'adoption' of the $2^{\circ} \mathrm{C}$ target has been the result, not of the UN negotiating process, but largely of the diplomatic efforts of various institutions of the European Union (EU). The $2^{\circ} \mathrm{C}$ target was first put forward in 1996 as a Conclusion of what is now the Council of the European Union [13, para 6] in order to push forward UN climate change negotiations which were even then giving 'concern' because they were 'not advancing as needed to achieve [their] intended objective' [13, para 1]. In a more or less unaccountable manner, the $2^{\circ} \mathrm{C}$ target was formulated by committees of the Commission and the Council and placed as an item not requiring substantial discussion on the agenda of a Meeting configured for environmental matters which also discussed, inter alia, humane animal trapping, pollution by non-road mobile machinery, and zoos. This Conclusion was 
justified by reference to the IPCC Second Assessment Report when, without arguing it here for reasons of space, it is quite wrong to claim that that Report, or indeed the subsequent Reports, did more than identify $2^{\circ} \mathrm{C}$ as one amongst a range of stabilisation targets ultimately derived from a huge number of possible 'emissions scenarios', and left the choice between the targets entirely to 'political processes'. There may be a consensus about climate change but unfortunately the IPCC has never been able to tell us what it is. ${ }^{2}$

This Council Conclusion has since been used as the justification of the adoption of the $2^{\circ} \mathrm{C}$ target by other EU bodies led by the Commission [eg 17, para 2], promotion of that target being stepped up after 2009 in order to 'reinvigorate' a UN process manifestly damaged by COP15 [18]. It has also, of course, been taken up by other national and international bodies [eg 19] including the UN, and is now at the heart of the Emissions Gap Report produced by the UN Environment Programme [20]. EU diplomacy which began with the Council Conclusion being made the basis of the EU negotiating position at COP2 in Geneva, has led to the $2^{\circ} \mathrm{C}$ target always appearing in reports of COP proceedings (but then only in such a way as to strictly divorce it from even the mere statement of any concrete commitment) between the KP and the PA, including in the CA. It no doubt strains the credulity of those not versed in the ways of transnational governance in general and EU governance in particular that one of the most important policies ever adopted could be adopted in this way, which has managed to completely avoid public justification of that adoption. But even recognising adoption of this sort, it is essential to distinguish this from actual agreement in international climate change law, which, to repeat, had not been achieved prior to the PA.

However, if Art 2.1 of the PA enters into force, then, as the EU intended [21, sec 2], the $2^{\circ} \mathrm{C}$ target will at last be incorporated into a legally binding Treaty. For readers' convenience, let me quote Art 2.1 again: 
This Agreement, in enhancing the implementation of the [FCCC], including its objective, aims to strengthen the global response to the threat of climate change, in the context of sustainable development and efforts to eradicate poverty, including by:

(a) Holding the increase in the global average temperature to well below $2^{\circ} \mathrm{C}$ above pre-industrial levels and pursuing efforts to limit the temperature increase to $1.5^{\circ} \mathrm{C}$ above pre-industrial levels, recognizing that this would significantly reduce the risks and impacts of climate change.

It can be seen that this is not an agreement of the $2^{\circ} \mathrm{C}$ or a $1.5^{\circ} \mathrm{C}$ target or of any target. It is a mere statement of aspiration 'to strengthen the global response to the threat of climate change', one part of the aspiration being towards 'Holding the increase in the global average temperature to well below $2{ }^{\circ} \mathrm{C}$ '. Nothing concrete whatsoever is said about this 'Holding'. It is true that Art 2(1)(a) is most unnecessarily convoluted drafting which conveys a misleading impression of concreteness, and it is this, I suggest, that has led Klein to distinguish what is said of $2^{\circ} \mathrm{C}$ from the even less concrete things that are said of $1.5^{\circ} \mathrm{C}$. But, far from it being right to claim that the PA 'commits to keeping warming below $2^{\circ} \mathrm{C}$ ', Art 2(1) constitutes the inability of more than a quarter century of international climate change negotiations to yield anything more than a mere expression of aspiration, even in respect of $2{ }^{\circ} \mathrm{C}$ or indeed any target.

\section{A change of strategy}

One immediately thinks that the process just described must constitute a very profound failure of policy-making, and I am of the opinion that indeed it does. But it in fact follows from a change of strategy about binding targets and binding commitments by leading proponents of climate change policy which Klein is representative in failing to grasp. I have previously discussed this change of strategy as it was expounded by a particularly important figure, Lord Stern, in the run-up to COP21 in Paris to which I refer readers [10], and I shall be brief here. 
Like very many others, Lord Stern had his fingers badly burned at COP15. In statements to the press, research reports and the like, and in a book written to encourage the reaching of an agreement in Copenhagen, he called COP15 'the most important international gathering [ie of any sort] since the Second World War' [22, p 208], and 'warned that Copenhagen is the world's last chance to stop catastrophic climate change' [23] and so 'save the world' [22]. The way the world was to be saved was that, despite acknowledgement of the 'major problem' of the NICs [22, p 157], COP15 was to yield an international, binding commitment to reduce global emissions: 'Copenhagen ... should produce detailed language for an international agreement on emissions reduction targets and the supporting mechanisms and institutions to achieve those targets' [24, p 145].

But in the run-up to COP21 in Paris, Lord Stern now told us that his 'own thoughts, and those of many others, have changed since ... COP15 in Copenhagen in 2009. Experience has taught us that real progress can be made without a formal international agreement' $[23, p$ 251]. This is just as well because, not merely does Lord Stern now maintain that 'looking for formal international sanctions within an agreement that have [sic] real "bite" may be a mistake' [23, p xviii], but he also tells us that 'trying to agree on a centralised and legalistic framework that "solves" climate change by attempting to bind countries to ambitious emissions reductions once and for all $\ldots$ is neither feasible nor sensible’ [23, p 220]. On this basis, COP21 was not described as another last chance to save the world but merely as providing 'an important opportunity to make strong progress in tackling climate change' [23, p 270]. The 'criteria for success in Paris' accordingly were stated as:

recognition of the scale of the challenge ... 'setting an appropriate shared goal ... which relates to, recognises the consequences of, and confirms the $2^{\circ} \mathrm{C}$ target [which has been] agreed ... recognition of the opportunities for growth, poverty reduction and beneficial structural change associated with strong action to reduce emissions [obtaining] Ambitious and credible contributions to emissions reductions by individual countries ... Sector-specific collaborations and commitments in areas such as decarbonising electricity [and] a shared recognition of the importance of equity in underpinning the long-term mitigation effort ... 
involving all countries making the transition to a decarbonised economy, with developed countries making earlier deep cuts and providing strong examples and strong assistance in finance, technology, innovation and knowledge to developing countries [23, pp 270-1].

Although, as we have seen, there has long been profound concern that international climate change negotiations were, to put it at the least, not making the progress desired, it became abundantly clear between the acrimonious COP15 in 2009 and the end of the First Commitment Period under the KP in 2012 [7, Art 3(7)] that the mitigation policy had failed. Emissions, far from being reduced, had enormously increased, and no agreement to reduce them had been reached. Lord Stern, rather more quickly than others, perceived that no such agreement would ever be reached. His response was, not to abandon the mitigation policy because of a failure to establish a necessary condition of its success, but to abandon the condition as a way of continuing with the policy. Parties were now to make their own minds up about what they wished to do, and, in a sort of refinement of the previous notification procedure under the CA, submit statements of their Intended Nationally Determined Contributions (INDCs) to the UN Climate Change Secretariat. ${ }^{3}$ These INDCs will be reviewed periodically and from this process it is hoped global reductions will result [2, Art 3]. The INDC is, for once, a FCCC instrument the name of which conveys what the instrument does. Nationally determined, the INDC is the basis of the unco-ordinated and nonbinding approach which has been adopted after a co-ordinated and binding approach has perforce been abandoned.

Apart from expressing my admiration of the ingenuity which has in this way so far kept the international climate change mitigation policy on the road despite, in my opinion, the wheels, never remotely securely fixed, having completely come off at Copenhagen, and emphasising that the new strategy represents the abandonment of any attempt ever to agree a binding $2^{\circ} \mathrm{C}$, or any, target for global emissions reductions, I am spared having to say anything about this change of strategy. For the sort of vaguely positive character which has 
been claimed for the INDC process in most official and other accounts of that process simply cannot survive proper interpretation of the PA as a whole. The new strategy is completely negated as the PA, in a continuation of the basic feature of climate change law since the FCCC, in fact categorically provides that there will be no emissions reductions by the developing countries, including the NICs, and so effectively provides that there will be no global emissions reductions by 2030 .

\section{What have the NIC's agreed to do?}

For the failure to agree the $2^{\circ} \mathrm{C}$ or any other target is by no means the worst failure of the PA.

Not merely is it not an agreement to reduce emissions, but it is an agreement to allow their unbounded growth. It will be recalled that the statement of aspiration in $\operatorname{Art} 2(1)(a)$ is made 'in the context of ... efforts to eradicate poverty'. This reference to 'efforts to eradicate poverty' must be read in light of Art 2(2) which provides that:

This Agreement will be implemented to reflect equity and the principle of common but differentiated responsibilities and respective capabilities, in the light of different national circumstances,

Other language to identical effect may be found throughout the PA [2, preamble, Art 4(3), Art 4(19)].

The basic strategy of climate change law under the FCCC has been to distinguish between developed and developing countries [3, Art 4(2)] and to ask both to recognise their 'common but differentiated responsibilities' to reduce emissions [3, preamble, Art 3(1), Art 4(1)]. Responsibility, both for historical emissions and for making reductions now, has been very much placed on the developed countries [3, preamble] as a matter of 'climate justice'. We have seen that the FCCC imposed no concrete reductions commitments on either developed or developing countries. But, crucially, FCCC Art 4(7), and much other language to identical effect, provided that: 
The extent to which developing country Parties will effectively implement their commitments under the [FCCC] will take fully into account that economic and social development and poverty eradication are the first and overriding priorities of the developing country Parties.

As, given foreseeable technology, emissions reductions which might significantly mitigate global warming must involve huge economic costs which seriously hinder poverty eradication, this provision means that there can be no significant limits placed on the emissions of developing countries which wish to pursue economic growth in order to eradicate poverty. And so, no caps have ever been placed on developing countries under the common but differentiated responsibilities strategy, because the FCCC Art 4(7) effectively stipulates that there cannot be. The common responsibilities of the developing countries are so differentiated that they do not exist.

As the NICs, including China and India, are classed as developing countries [3, Art 4(2), Annex I, Annex II], this has meant the mitigation policy was bound to fail from the start, has failed, and will fail. The permission given to these countries by the FCCC to emit as much as they see fit was affirmed in the KP [7, Art 10] and at all of the climate change conferences including and subsequent to Copenhagen [11, para 1], now including Paris.

In light of all this, it is arguably supererogatory to now add that the PA actually strengthens the permission granted to China and India not to make reductions. Art 4(4) of the PA provides that:

Developed country Parties should continue taking the lead by undertaking economy-wide absolute emission reduction targets. Developing country Parties should continue enhancing their mitigation efforts, and are encouraged to move over time towards economy-wide emission reduction or limitation targets in the light of different national circumstances.

‘Absolute' emissions reductions are actual reductions of emissions. Other 'mitigation efforts' are in this provision explicitly distinguished from absolute emissions reductions and the developing countries, including the NICs, are asked only to 'continue enhancing [these other] efforts'. The implicit, though categorical enough, permission to increase emissions under Art 
4(7) of the FCCC is now strengthened by an explicit provision under Art 4(4) of the PA that

China and India categorically will not be required to make absolute emissions reductions.

The mitigation effort, defined as something other than absolute reductions, that has been most discussed in the formulation of the mitigation policy is reduction in carbon intensity. When, for example, reviewing the Fourth Carbon Budget [25, pp 42-43], ${ }^{4}$ the Committee on Climate Change said of China that:

in the Copenhagen Accord China pledged to reduce its carbon intensity by 40$45 \%$ by 2020 compared to 2005 levels. In 2011 China adopted its 12 th five-year plan, covering the period 2011-15. This set out the policies planned to put China on track to meet its 2020 carbon intensity target ... Evidence suggests that measures already in place, together with those set out in the 12th five-year plan, mean the high ambition of China's Copenhagen Pledge for 2020 is achievable .. recent policy announcements, if agreed and delivered, could put Chinese emissions on a trajectory consistent with the global emissions pathways required to meet our climate objective.

I have argued elsewhere that everything about this is wrong [10, pp 406-407], and I

want here to discuss, not the Committee on Climate Change specifically, but carbon intensity in general. Reduction in carbon intensity and reduction in absolute emissions must be strongly distinguished. Carbon intensity is a measure of the amount of $\mathrm{CO}_{2} \mathrm{e}$ which must be emitted to obtain a certain increase in gross domestic product (gdp). Such a reduction carries no implication that it will involve an absolute reduction of emissions. Broadly speaking, absolute emissions and economic growth are strongly correlated, but, with increasing sophistication of technology, the rate at which growth requires emissions, that is to say, carbon intensity, falls. The history of western industrialisation is itself one of a reduction in carbon intensity which, without a technological miracle, will never be surpassed, but a reduction brought about, of course, by the immense growth in absolute emissions now blamed for anthropological global warming, a growth which now is in the course of being surpassed by the NICs. 
In what follows I will, for reasons of brevity, discuss only China but the position is essentially the same for all the NICs including India, which is especially significant because India is in essence a duplicate of China, but running at least a decade behind. China's economic growth will, as the Committee on Climate Change claims, involve a reduction of carbon intensity as new plant is installed and old plant is retired. But reduction in carbon intensity may be perfectly consistent with unbounded absolute growth in emissions, depending on how much economic growth there is, and such are China's economic growth targets that its reductions in carbon intensity will be made, not despite but because of, a growth in absolute emissions. China will not retire existing generating capacity and replace it only with an equivalent or smaller capacity generated by lower intensity plant. It will retire older capacity in the course of an immense expansion of overall capacity. In such circumstances, as new plant is installed and old plant is retired, carbon intensity falls, but the fall is obtained through absolute growth of emissions, and the faster the fall in intensity, the greater the rise in absolute emissions. China's extremely ambitious and apparently positive intensity targets actually represent a statement that the increase in its emissions will be vast.

The situation is confirmed in China's INDC, ${ }^{5}$ the burden of which is very similar to the position under the PA. The first thing to place firmly at the forefront of one's thinking is the immense size of China's population. At 1.3 billion, that population is a billion larger than that of the US and almost a billion larger than that of the EU. Since 1979, China has embarked on an enormously successful programme of economic growth and poverty relief. However, this success remains largely confined to its coastal cities. In its enormous hinterland, almost a billion people still live on less than US\$5/day and almost half a billion on US\$2.50. Despite the growth since 1979, the extent of this continuing poverty is reflected in China still being only the third largest economy in the world after the US and the EU regarded as a whole (though it is confidently predicted that by 2020 it will become clearly the largest), and 
China's emissions per capita still being less than $50 \%$ of the EU and less than $25 \%$ of the US. China's basic economic policy goal, stated in its economic plan and reiterated in its INDC [29, p 4], is to create a 'moderately prosperous' society by 2020 and a 'prosperous' society by 2050. If this is, as it should be, taken to mean achieving a per capita gdp comparable to the west, it obviously will involve a further absolute growth of the Chinese economy that can only be described as astronomical. In particular, though China has been responsible for $80 \%$ of the almost doubling of world coal consumption this century, and though it now consumes as much coal as the rest of the world combined, its plan to 2030 involves a further almost doubling of coal-fired generation.

China's INDC must be read against this background. It [30, p 5] says that:

Based on its national circumstances, development stage, sustainable development strategy and international responsibility, China has nationally determined its actions by 2030 as follows:

- To achieve the peaking of carbon dioxide emissions around 2030 and making best efforts to peak early;

- To lower carbon dioxide emissions per unit of gdp by $60 \%$ to $65 \%$ from the 2005 level;

- To increase the share of non-fossil fuels in primary energy consumption to around $20 \%$

I must confess I do not understand the first of these commitments. It cannot mean a peaking in the growth of absolute emissions, because on foreseeable technology this would effectively mean a peaking in economic growth, and it is not conceivable that China would commit to this. I think it must refer to a peaking in the rate of growth of absolute emissions, related to a reduction in growth of gdp, down from the previous $10 \%$ per annum or the current $6.5 \%$ to levels comparable to the mature economies of the west. This would be consistent with the second commitment, which is to lower carbon intensity, the implications of which for absolute emissions reductions have already been discussed. The commitment to increase the share of non-fossil fuels will be part of the reduction in carbon intensity, but it is itself perfectly compatible with an increase in absolute emissions, and, as I have explained 
elsewhere [31], this is exactly what will happen in the context of China's plans for growth. A growth in the small share of non-fossil fuels in China's energy mix will not prevent enormous growth in emissions by Chinese energy generation which is planned to double by 2030 and which will remain overwhelmingly dominated by fossil fuels, principally coal.

What is more, China's INDC [308, p 17] sets out the complete allocation of responsibility for absolute emissions reductions up to 2030 to the developed countries, and the corollary complete exemption from such responsibility of the developing countries, which was adopted in almost identical language in the PA:

The [PA] shall stipulate that the Parties, in accordance with the provisions of the [FCCC], shall formulate and implement programs and measures to reduce or limit greenhouse gas emissions for the period 2020-2030 and promote international cooperation on mitigation. Developed countries shall, in accordance with their historical responsibilities, undertake ambitious economy-wide absolute quantified emissions reduction targets by 2030. Developing countries shall, in the context of sustainable development and supported and enabled by the provision of finance, technology and capacity building by developed countries, undertake diversifying enhanced mitigation actions.

In light of what has been said of the PA, further comment on the significance of this is supererogatory.

\section{Conclusion}

Considered as an exercise in regulation, the international climate change policy of mitigation of global warming could not really be more significant. As I have elsewhere [4] argued more extensively than I propose to do here, and so the reader is referred to that discussion for theoretical elaboration and referencing, that policy shows both familiar and novel features, and the novel features are remarkable. In a way which is so very familiar a part of the modern welfare economics case for government intervention that it has become central to educated public opinion, $\mathrm{CO}_{2} \mathrm{e}$ emissions are described as a 'negative externality' calling for the mitigation policy as an intervention necessary to obtain emissions reductions. There are, 
however, two principal novelties. First, coming in a period when faith in more direct, command and control styles of intervention had waned, the mitigation policy was to be based on the 'market-mimicking' strategy of 'carbon trading'. This can be put to one side. But, secondly, and of crucial relevance to us here, as emissions anywhere in the world can contribute to the increase in the atmospheric concentration of $\mathrm{CO}_{2} \mathrm{e}$, global warming is a global problem. The response has to be global, and the mitigation policy was the first intervention to be conducted at a truly global scale and scope. I have previously called international climate change policy 'global welfare economics' [4, pp 164-7], but this feature of climate change policy has perhaps been better captured in the rather good pun on the environmental and global aspects of 'planetary economics' in the title of a book on the subject by a leading academic proponent of that policy [32].

Behind the interpretation of the PA put forward in this paper lies the belief, which I formed more than a decade ago, that this enormously important development in regulatory theory and practice has been an absolute failure. This belief allowed me to predict the content of the PA, were a legally binding agreement to be reached in Paris [33], though I must confess I was completely unsure whether any agreement would be reached. The basic legal agreement necessary for the mitigation policy to work has never been able to be put into place and indeed what has been agreed has categorically made that policy impossible from the start, impossible now, and impossible in the future. Lord Stern [34, p 1] has claimed that global warming is 'the greatest example of market failure we have ever seen'. It is at least as arguable that the international climate action policy of mitigation is the greatest example of peacetime government failure we have ever seen. 


\section{Notes}

${ }^{1}$ This Evidence was also the basis of a public lecture given under the auspices of the Global Warming Policy Foundation in the House of Lords, July 2016.

2 The reasons of space arise from the enormous length, complexity in the good sense and complicatedness in the bad sense, including a pronounced repetitiveness which is often the more maddening because it introduces inconsistencies, of each of these Assessment Reports, features which are, of course, amplified if one considers all the Reports constituting a particular assessment, not to speak of their associated publications. The briefing note prepared for delegates to COP2 in Geneva where the Council Conclusion began to take international root has a rather touchingly despairing tone note about the Second Assessment Report in this respect [14]. Because what the Assessment Reports have said is tantamount to impossible to grasp as a whole, it is equally tantamount to impossible to give a clear summary of what the IPCC has said about $2^{\circ} \mathrm{C}$ as a target.

It is perhaps sufficient here to note that the Synthesis of the Second Assessment Report to which the Council refers is careful to insist, when reviewing the scenarios including the $2^{\circ} \mathrm{C}$ scenario, that 'These examples do not represent any form of recommendation about how such stabilization levels might be achieved or the level of stabilization which might be chosen' [15, para 4]. I fear I will not be believed by those who have not tried to read the Assessment Reports when I say that the best reason the IPCC has come up with for focusing on 1.5 or $2^{\circ} \mathrm{C}$ is that they are 'widely discussed goals' [16, p 113], and has acknowledged that the provision of such clarity as there is about the $2^{\circ} \mathrm{C}$ target is the result of 'a series of high level-political events' [16, para 1.2.6]. In sum, the IPCC [16, para 1.2.6] is careful to make it clear it has no view on which scenario should guide policy. 
${ }^{3}$ Prior to its ratification of the PA, a Party should, under PA Art 4(2), communicate what will then be regarded as its 'Nationally Determined Contribution' in a Registry in the process of being established by the UNFCCC Secretariat. A Party may modify its INDC when communicating its NDC. China ratified the PA and communicated its NDC on 3 September 2016. Its NDC is identical to its INDC; indeed it is the all but identical document.

${ }^{4}$ The position is very briefly restated in the Committee's Fifth Carbon Budget Review [26, $\mathrm{p}$ 79].

${ }^{5}$ I will not give detailed references to what is intended merely to be an overview of the Chinese position. Apart from the Chinese plans for energy and growth generally which lay behind its INDC, the principal sources are the World Development Report 2010 (as updated) [19], the International Energy Outlook [27], the World Energy Outlook [28] and the Emissions Gap Report [20]. 


\section{References}

[1] Campbell D. The Implications of the Paris Agreement for Setting a Fifth Carbon Budget. Evidence to the Energy and Climate Change Committee Inquiry into Setting a Fifth Carbon Budget, Fifth Report: Setting the Fifth Carbon Budget (2015-16) HC 259, FCB0050.

Available from:

http://data.parliament.uk/writtenevidence/committeeevidence.svc/evidencedocument/energyand-climate-change-committee/setting-the-fifth-carbon-budget/written/30181.html

[2] Paris Agreement. Opened for signature 16 February 2016. UN MTDSG

C.N.92.2016.TREATIES-XXVII.7.d (Depositary Notification). Available from:

http://unfccc.int/files/essential_background/convention/application/pdf/english_paris_agreem $\underline{\text { ent.pdf }}$

[3] Framework Convention on Climate Change. Opened for signature 9 May 1992, entered into force 21 March 1994. 1771 UNTS 107. Available from:

http://unfccc.int/files/essential_background/background_publications htmlpdf/application/pd f/conveng.pdf

[4] Campbell D, Klaes M, Bignell, C. After Cancun: The Impossibility of Carbon Trading. University of Queensland Law Journal. 2010; 29(2): 163-90.

[5] UN General Assembly, Protection of Global Climate for Present and Future Generations of Mankind, 70th Plenary Meeting of the General Assembly. 6 December 1988.

A/RES/43/53. Available from:

http://www.un.org/en/ga/search/view_doc.asp?symbol=A/RES/43/53\&Lang=E\&Area=RESO

$\underline{\text { LUTION }}$

[6] Klein N. Let Them Drown. 2016 Edward Said Lecture. London Review of Books. 2 June 2016; 38(11): 11-14. Available from http://www.lrb.co.uk/v38/n11/naomi-klein/let-themdrown 
[7] Kyoto Protocol to the United Nations Framework Convention on Climate Change.

Opened for signature 11 December 1997, entered into force 16 February 2005. 2302 UNTS

148. Available from: http://unfccc.int/resource/docs/convkp/kpeng.pdf

[8] Campbell, D. What is Climate Change Policy Now Trying to Achieve? Economic Affairs. $2015 ; 35(3): 428-42$.

[9] Campbell D. After Doha: What Has Climate Change Policy Accomplished? Journal of Environmental Law. 2013; 25(1): 125-36.

[10] Campbell, D. How UK Climate Change Policy Has Been Made Sustainable. Social and Legal Studies. 2015; 24(3): 399-418.

[11] UNFCCC. Copenhagen Accord. Report of the Conference of the Parties on its Fifteenth Session, Held in Copenhagen from 7 to 19 December 2009, Part 2: Action taken by the Conference of the Parties at its Fifteenth Session. 30 March 2010. FCCC/CP/2009/11/Add.1, Decision 2/CP/15. Available from: http://unfccc.int/resource/docs/2009/cop15/eng/11a01.pdf [12] Klein, N. This Changes Everything. London: Penguin Books; 2015.

[13] Council of the European Union. Community Strategy on Climate Change: Council Conclusions, 1939th Meeting, 25-26 June 1996, Luxembourg. Available from: http://europa.eu/rapid/press-release_PRES-96-188_en.htm

[14] UNFCCC. Scientific Assessments: Consideration of the Second Assessment Report of the Comment [MJ2]: I don't find this title in the website you cite, and so have suggested a different title. Can you cite an additional or different source containing your title?

Comment [MJ3]: Not Luxembourg?

FCCC/SBSTA/1996/7/Rev.1. Available from:

http://unfccc.int/cop5/resource/docs/cop2/05.pdf

[15] IPCC. Climate Change 1995: IPCC Second Assessment Synthesis of Scientific-technical Information Relevant to Interpreting Article 2 of the UN Framework Convention on Climate Change. Available from: http://www.ipcc.ch/pdf/climate-changes-1995/ipcc-2ndassessment/2nd-assessment-en.pdf 
[16] IPCC, Climate Change 2014: Mitigation of Climate Change. Contribution of WGIII to the IPCC 5th Assessment Report. Cambridge: Cambridge University Press; 2015. Available from: https://www.ipcc.ch/pdf/assessment-report/ar5/wg3/ipcc_wg3 ar5 full.pdf [17] EU Commission, Winning the Battle Against Global Climate Change. Communication from the Commission to the Council, etc. 9 February 2005. COM(2005) 35 final. Available from: http://eur-lex.europa.eu/legal-

content/EN/TXT/PDF/?uri=CELEX:52005DC0035\&from=EN

[18] EU Commission. International Climate Policy Post-Copenhagen: Acting Now to Reinvigorate Global Action on Climate Change. Communication from the Commission to the European Parliament, etc. 9 March 2010. COM(2010) 86 final. Available from: http://eurlex.europa.eu/legal-content/EN/TXT/PDF/?uri=CELEX:52010DC0086\&from=EN

[19] World Bank. World Development Report 2010: Development and Climate Change.

Washington DC: World Bank; 2010. Available from:

http://siteresources.worldbank.org/INTWDRS/Resources/477365-1327504426766/8389626-

\section{6/Overview.pdf}

[20] UNEP. The Emissions Gap Report 2015: Advance Copy. Nairobi: UNEP; 2015.

Available from: http://uneplive.unep.org/media/docs/theme/13/EGR_2015 301115 lores.pdf [21] EU Commission. The Paris Protocol: A Blueprint for Tackling Global Climate Change Beyond 2020. Communication from the Commission to the European Parliament and the Council. 4 March 2015. COM(2015) 81 final/2. Available from: http://eurlex.europa.eu/resource.html?uri=cellar:e27fdb4d-bdce-11e4-bbe1-

01aa75ed71a1.0003.03/DOC_1\&format=PDF

[22] Stern, N. A Blueprint for a Safer Planet: How We Can Save the World and Create Prosperity. London: Vintage; 2009. 
[23] Gray, L (2009) Copenhagen Summit Is Last Chance To Save the Planet, Lord Stern. Daily Telegraph, 2 December 2009. Available from:

http://www.telegraph.co.uk/news/earth/copenhagen-climate-changeconfe/6701307/Copenhagen-summit-is-last-chance-to-save-the-planet-Lord-Stern.html [24] Stern N. Why Are We Waiting? The Logic, Urgency, and Promise of Tackling Climate Change. Cambridge, MA: MIT Press; 2015.

[25] Committee on Climate Change. Fourth Carbon Budget Review - Part 1: Assessment of Climate Risk and the International Response. 2013. Available from: http://www.theccc.org.uk/publication/fourth-carbon-budget-review-part-1/ [26] Committee on Climate Change. The Fifth Carbon Budget. 2015. Available from: http://www.theccc.org.uk/publication/fourth-carbon-budget-review-part-1/ [27] United States Energy Information Administration. International Energy Outlook 2016. DOE/EIA-0484(2016). Washington DC: USIEA; May 2016. Available from: http://www.eia.gov/forecasts/ieo/pdf/0484(2016).pdf [28] International Energy Agency. Energy and Climate Change: World Energy Outlook Special Report 2016. Paris: OECD/IEA; May 2015.

[29] United Nations Environment Programme. The Emissions Gap Report 2015. Nairobi: UNEP; 2015. Available from: http://uneplive.unep.org/media/docs/theme/13/EGR_2015_301115_lores.pdf [30] Department of Climate Change, PRC, Enhanced Actions on Climate Change, China's Intended Nationally Determined Contribution, submitted on 30 June 2015. Available from: http://www4.unfccc.int/Submissions/INDC/Published\%20Documents/China/1/China's\%20IN DC\%20-\%200n\%2030\%20June\%202015.pdf 
[31] Campbell, D. Is China's Use of Coal Really Declining? Global Warming Policy Foundation blog. 16 May 2016. Available from: http://www.thegwpf.com/is-chinas-use-ofcoal-really-declining/

[32] Grubb, M. Planetary Economics: Energy, Climate Change and the Three Domains of Sustainable Development. London: Routledge; 2014.

[33] Campbell, D. Short Cuts. London Review of Books. 5 November 2015; 37(21): 32.

Available from: http://www.lrb.co.uk/v37/n21/david-campbell/short-cuts

[34] Stern N. The Economics of Climate Change: The Stern Review. Cambridge: Cambridge University Press; 2007. Available from:

http://webarchive.nationalarchives.gov.uk/20100407172811/http://www.hm-

$\underline{\text { treasury.gov.uk/stern review report.htm }}$ 